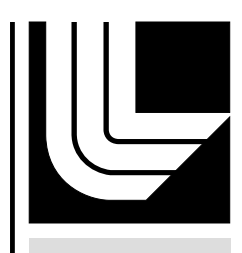

LA W REN CE LIVERM ORE N A TIO NAL LABORATORY

Newberry Seismic Deployment Fieldwork Report

J. Wang, D. C. Templeton

March 27, 2012 
This document was prepared as an account of work sponsored by an agency of the United States government. Neither the United States government nor Lawrence Livermore National Security, LLC, nor any of their employees makes any warranty, expressed or implied, or assumes any legal liability or responsibility for the accuracy, completeness, or usefulness of any information, apparatus, product, or process disclosed, or represents that its use would not infringe privately owned rights. Reference herein to any specific commercial product, process, or service by trade name, trademark, manufacturer, or otherwise does not necessarily constitute or imply its endorsement, recommendation, or favoring by the United States government or Lawrence Livermore National Security, LLC. The views and opinions of authors expressed herein do not necessarily state or reflect those of the United States government or Lawrence Livermore National Security, LLC, and shall not be used for advertising or product endorsement purposes.

This work performed under the auspices of the U.S. Department of Energy by Lawrence Livermore National Laboratory under Contract DE-AC52-07NA27344. 


\title{
Newberry Seismic Deployment Fieldwork Report
}

\author{
Bend, Oregon, Oct 30 - Nov 4, 2011
}

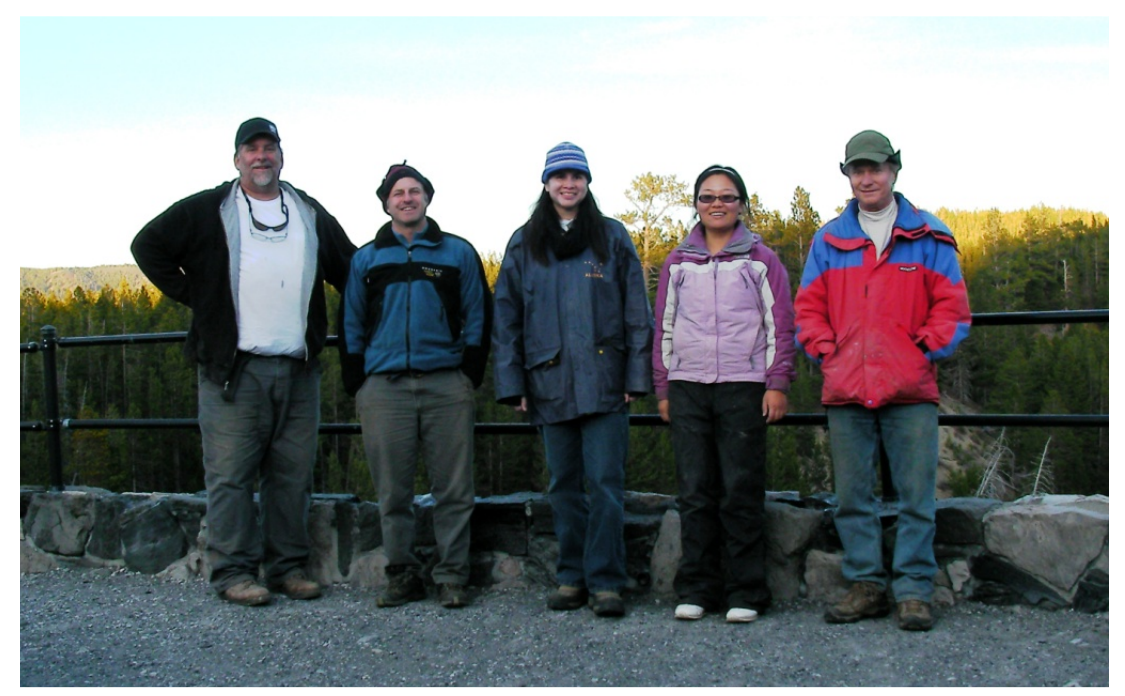

Pat Lewis, Trenton Cladouhos, Dennise Templeton, JingboWang, and Phil Harben (from left to right)

AEED

$\bigsqcup$ Lawrence Livermore 


\section{Contents:}

1. Introduction 2

2. Deployment Outline 3

2.1 Personnel Involved 3

2.2 Equipment Used 3

2.3 Typical Site Setup 3

3. Deployment Narrative 4

4. List of Station Locations 5

5. Problems Encountered 7

$\begin{array}{lll}5.1 & \text { Instruments } & 7\end{array}$

$\begin{array}{lll}5.2 & \text { Noise } & 7\end{array}$

6. Archiving of Data 7

7. Pumping and Perforation Shot Times

8. Acknowledgements 8

9. Site Location Photos 8 


\section{Introduction}

This report summarizes the seismic deployment of Lawrence Livermore National Laboratory (LLNL) Geotech GS-13 short-period seismometers at the Newberry Enhanced Geothermal System (EGS) Demonstration site located in Central Oregon. This Department of Energy (DOE) demonstration project is managed by AltaRock Energy Inc. AltaRock Energy had previously deployed Geospace GS-11D geophones at the Newberry EGS Demonstration site, however the quality of the seismic data was somewhat low. The purpose of the LLNL deployment was to install more sensitive sensors which would record higher quality seismic data for use in future seismic studies, such as ambient noise correlation, matched field processing earthquake detection studies, and general EGS microearthquake studies.

For the LLNL deployment, seven three-component seismic stations were installed around the proposed AltaRock Energy stimulation well (Fig.1). The LLNL seismic sensors were connected to AltaRock Energy Güralp CMG-DM24 digitizers, which are powered by AltaRock Energy solar panels and batteries. The deployment took four days in two phases. In phase I, the sites were identified, a cavity approximately 3 feet deep was dug and a flat concrete pad oriented to true North was made for each site. In phase II, we installed three single component GS-13 seismometers at each site, quality controlled the data to ensure that each station was recording data properly, and filled in each cavity with native soil.

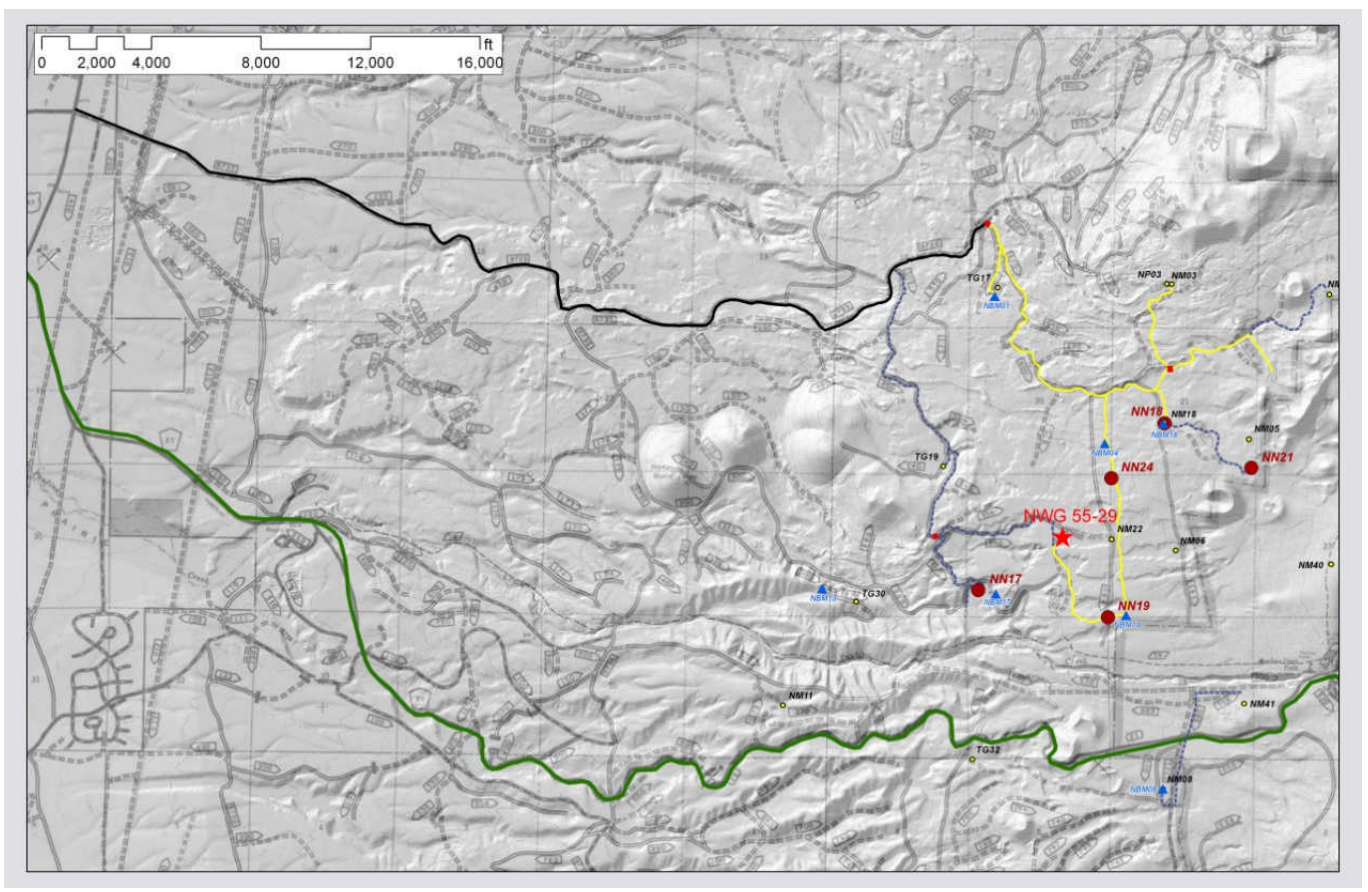

Fig.1: Location of LLNL seismic stations as blue triangles. Black, yellow and green lines indicate the locations of the three main access roads. The proposed stimulation well is indicated by the red star. Future proposed AltaRock Energy seismic stations are indicated by the red circles. 


\section{Deployment Outline}

\subsection{Personnel Involved}

LLNL:

- Dennise Templeton, Jingbo Wang, Phil Harben, Pat Lewis

AltaRock Energy Inc:

- Trenton Cladouhos

\subsection{Equipment Used}

The following equipment was used in the deployment:

- 21 GS-13 short-period seismometers

- 7 Güralp CMG-DM24 digitizers

- 7 Solar panels

- 7 Batteries

- 7 GPS units

- 1 Laptop running Güralp Scream! software

\subsection{Typical Site Setup}

The dimensions of the cavity in which the seismic sensors were installed was approximately $3 \times 3 \times 2.5 \mathrm{ft}^{3}$ for each site. The cavity was hand dug and the bottom made flat. A wooden frame was placed in each cavity and levelled with the aid of a bubble level. A mixture of concrete, bonding additive and water was mixed in the field, poured into the wooden frame, and allowed to cure for at least 12 - 24 hours. The sensors were then placed on the flat surface of the concrete pad at the bottom of the hole. The two horizontal components were orientated to true North and East, assuming a declination of $15^{\circ} \mathrm{E}$ (Fig. 2 ). The instruments were then levelled and unlocked. We also verified that the mass of each component could freely oscillate within the seismometer.

The seismic sensors were connected to resistors, which damped them at .7 critical damping resistance (CDR). Both the sensors and resistors were covered by a drop-down fibreglass enclosure. A large plastic tarp was placed over the enclosure and native soil was backfilled around the enclosure until the cavity was completely filled in again. Care was taken during this process so that the sensors would not be moved. At sites where the ground was flat, a second tarp was placed slightly below ground level and then covered with native soil, rocks and logs. 

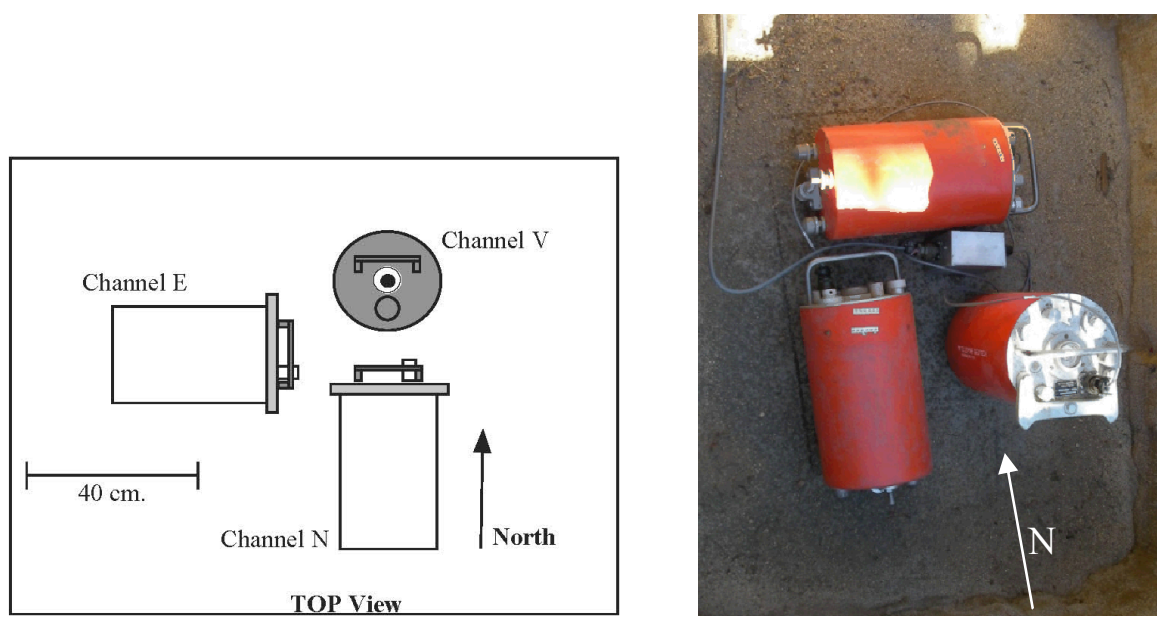

Fig. 2: On the left, schematic showing a three-component GS-13 site (adapted from IRIS website: www.iris.edu.) On the right, a photo from a typical Newberry deployment site of the three single-component seismometers and the resistor box.

The cables from the sensors to the recording system were buried in a shallow trench. A small amount of slack was allowed between the sensors and the digitizers to prevent the sensor from being pulled (except at one station, see notes below). A solar panel and $1-2$ batteries power each recording system. The digitizers were programmed to record continuously at 250 samples per second (SPS). The recording system and batteries were well sealed inside a Hoffman box, a $1 \times 0.8 \times 0.5 \mathrm{ft}^{3}$ metal box, to prevent possible damage by both wildlife and weather. The GPS and solar panels were mounted on nearby pine trees.

\section{Deployment Narrative}

Prior to the field deployment, the LLNL team inspected, modified, and repaired the seismometers as necessary. For example, upon initial inspection, it was discovered that most of the GS-13s were oriented vertically. A significant number of the vertical components had to be converted to be oriented horizontally. After conversion, 9 groups of three-component seismometers were created: 8 for the original 8 seismic stations proposed and one extra three-component set for possible emergency replacement in the field.

We had initially planned on deploying 8 sites. However, due to a lack of solar panels, a field decision was made to remove Site NBM03 from the deployment plan.

The four-day field deployment was divided into two phases. The first two days were devoted to digging out the old AltaRock GS-11D geophones, digging the cavity for the current LLNL sensors, levelling the bottom of the hole, and making the concrete pad at the bottom of the hole. At most sites, the LLNL sensors were placed in the same location as the original AltaRock sensors. The second phase consisted in installing the seismic sensors and the subsequent clean up procedure. 
Our working schedule depended greatly on the weather conditions. Since there was a high chance of snow on 11/03/2011, we concentrated on finishing up the deployment before the heavy snow would arrive.

10/31/2011 Sites NBM01, 04, 18, and 19 were identified. Cavities were dug at Sites NMB01, 04, and 19. The geology was strikingly similar at all sites and was composed of several feet of volcanic ash. At approximately 2 feet deep, we typically began to encounter a few volcanic bombs. In general, it was easy digging, however such geology is not necessarily the best for seismic coupling. Concrete pads were constructed at Sites NBM04 and 19.

11/01/2011 Sites NBM13, 17, and 08 were identified. Cavities were dug at Sites NBM18, 13, 17, and 08. Concrete pads were constructed at all remaining sites.

11/02/2011 Sites NBM04, 19, 13 and 17 were deployed.

11/03/2011 Sites NBM01, 18, 08 were deployed. Immediately after we finished deploying NBM08, the snowfall began in earnest.

\section{List of Station Locations}

Details of locations and station information are given in Table 1 and 2. LLNL station locations are shown in Fig 3.

Table 1: Locations and deployments of GS-13 instruments.

\begin{tabular}{|l|c|c|c|c|}
\hline Station & $\begin{array}{c}\text { Approximate Activation } \\
\text { Time (Local Time) }\end{array}$ & Lat. $\left({ }^{\circ} \mathbf{N}\right)$ & Long. $\left({ }^{\circ} \mathbf{W}\right)$ & $\begin{array}{c}\text { Alt. } \\
(\mathbf{f t})\end{array}$ \\
\hline NBM04 & $11 / 02 / 201109: 30 \mathrm{am}$ & 43.73537 & 121.31049 & 5878 \\
\hline NBM19 & $11 / 02 / 201111: 00 \mathrm{am}$ & 43.71852 & 121.30659 & 5862 \\
\hline NBM13 & $11 / 02 / 201102: 30 \mathrm{pm}$ & 43.72049 & 121.34871 & 5173 \\
\hline NBM17 & $11 / 02 / 201103: 45 \mathrm{pm}$ & 43.72035 & 121.32468 & 5648 \\
\hline NBM18 & $11 / 03 / 201109: 30 \mathrm{am}$ & 43.7380 & 121.30251 & 6007 \\
\hline NBM01 & $11 / 03 / 201110: 35 \mathrm{am}$ & 43.75164 & 121.32446 & 5552 \\
\hline NBM08 & $11 / 03 / 201102: 30 \mathrm{pm}$ & 43.70070 & 121.30292 & 6010 \\
\hline
\end{tabular}


Table 2: Sensor information for LLNL seismic stations.

\begin{tabular}{|c|c|c|c|c|}
\hline Station & $\begin{array}{l}\text { Serial } \\
\text { No. }\end{array}$ & $\begin{array}{c}0.7 \text { of CDR } \\
(\mathrm{K} \mathrm{ohm})\end{array}$ & $\begin{array}{l}\text { Manufactured } \\
\text { resistor } \\
\text { (Kohm) } \\
\end{array}$ & Comments \\
\hline NBM01 & & & & $\begin{array}{c}\text { Verified correct resistor box } \\
\text { installed: Box 1. Site located on a } \\
\text { hill. }\end{array}$ \\
\hline $\mathrm{V}$ & 112 & 98.0 & 97.6 & \\
\hline $\mathrm{N}$ & 129 & 109.2 & 110 & \\
\hline $\mathrm{E}$ & 261 & 110.6 & 110 & \\
\hline NBM04 & & & & $\begin{array}{c}\text { Verified correct resistor installed: } \\
\text { Box } 4 \\
\end{array}$ \\
\hline $\mathrm{V}$ & 115 & 95.6 & 95.3 & \\
\hline $\mathrm{N}$ & 111 & 95.5 & 95.3 & \\
\hline $\mathrm{E}$ & 114 & 94.5 & 95.3 & \\
\hline NBM08 & & & & $\begin{array}{c}\text { Verified correct resistor box installed: } \\
\text { Box } 8\end{array}$ \\
\hline $\mathrm{V}$ & 293 & 116.0 & 115 & \multirow{3}{*}{$\begin{array}{l}\text { There was } 30 \text { ' of cable and the distance } \\
\text { between digitizer and sensor is almost } \\
\text { exactly } 30 \text { '.. Do not pull this cable } \\
\text { when collecting instrument. Vertical } \\
\text { sensor } \# 286 \text { initially assigned to this } \\
\text { site was switch for } \# 293 \text { in the field. }\end{array}$} \\
\hline $\mathrm{N}$ & 288 & 117.2 & 118 & \\
\hline$E$ & 296 & 116.7 & 118 & \\
\hline NBM13 & & & & $\begin{array}{l}\text { Resistor Box } 13 \text { or } 18 \text { installed. Site } \\
\text { located up on a hill. Wind noise may } \\
\text { be a problem. }\end{array}$ \\
\hline $\mathrm{V}$ & 131 & 110.0 & 110 & \\
\hline $\mathrm{N}$ & 133 & 110.3 & 110 & \\
\hline$E$ & 283 & 112.0 & 113 & \\
\hline NBM17 & & & & $\begin{array}{l}\text { Resistor Box } 13 \text { or } 18 \text { installed. } \\
\text { Close to the back up water well. }\end{array}$ \\
\hline $\mathrm{V}$ & 286 & 116.6 & 118 & \multirow{3}{*}{$\begin{array}{l}\text { The vertical component seismometer } \\
\text { (\#287) initially assigned to this site } \\
\text { was broken when installation began. } \\
\text { Switched with vertical component } \\
\text { \#286 in the field. }\end{array}$} \\
\hline $\mathrm{N}$ & 292 & 119.0 & 118 & \\
\hline $\mathrm{E}$ & 289 & 117.4 & 118 & \\
\hline NBM18 & & & & Resistor Box 17 installed \\
\hline $\mathrm{V}$ & 291 & 127.3 & 118 & \\
\hline $\mathrm{N}$ & 295 & 119.5 & 118 & \\
\hline $\mathrm{E}$ & 285 & 119.4 & 118 & \\
\hline NBM19 & & & & $\begin{array}{l}\text { Verified correct resistor installed: } \\
\text { Box } 19\end{array}$ \\
\hline $\mathrm{V}$ & 132 & 110.0 & 110 & \\
\hline $\mathrm{N}$ & 276 & 116.0 & 115 & \\
\hline $\mathrm{E}$ & 265 & 115.8 & 115 & \\
\hline NBM03 & & & & $\begin{array}{l}\text { Removed from field deployment } \\
\text { plan. }\end{array}$ \\
\hline $\mathrm{V}$ & 293 & 116.0 & 115 & \\
\hline $\mathrm{N}$ & 273 & 115.9 & 115 & \\
\hline $\mathrm{E}$ & 284 & 115.8 & 115 & \\
\hline
\end{tabular}




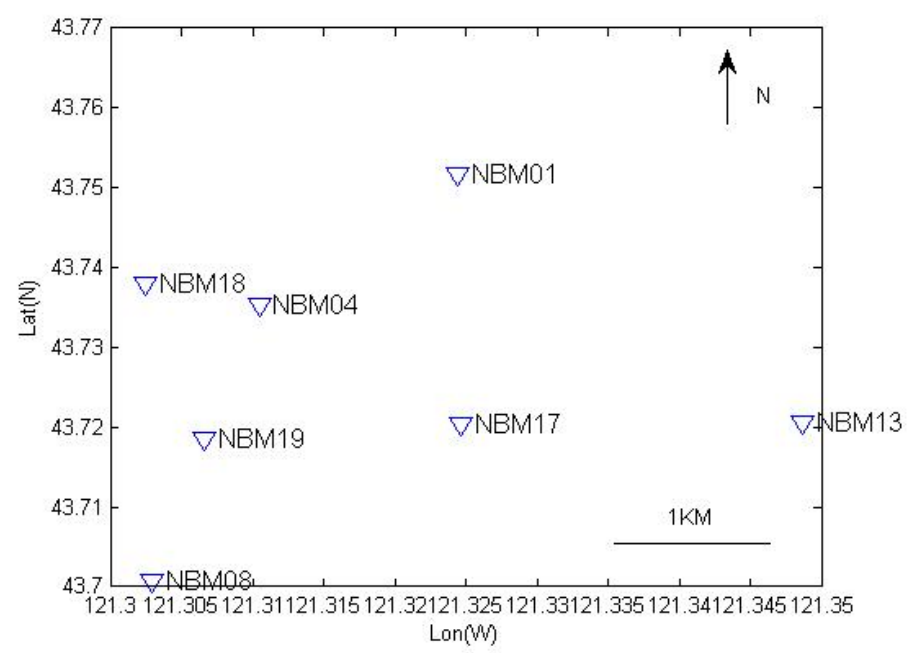

Fig. 3: LLNL station location map.

\section{Problems Encountered}

\subsection{Instruments}

The vertical sensor \#287 initially assigned to site NBM17 was broken. We performed a field replacement with vertical sensor \#286. The vertical sensor \#286 was initially assigned to site NBM08, but was replaced by vertical sensor \#293. The vertical sensor \#293 was initially assigned to site NBM03, which was removed from the deployment plan. It was important to swap sensors with similar CDR because the resistors that provided the damping were individually manufactured prior to deployment to a particular sensor with a particular damped CDR.

\subsection{Noise source}

Except for NBM08, as the roads near the deployment sites only allow authorized vehicles, we expect that the traffic noise will be low.

\section{Archiving of Data}

All of the data will be collected by AltaRock Energy in Guralp Compressed Format (GCF) and given to Lawrence Berkeley National Laboratory and LLNL for archiving.

\section{Hydraulic fracture schedule}

The hydraulic fracture is tentatively scheduled for May 2012. 


\section{Acknowledgements}

This work was performed under the auspices of the U.S. Department of Energy by Lawrence Livermore National Laboratory under Laboratory Directed Research \& Development (LDRD) Proposal: Creating Optimal Fracture Networks with the tracking number 11-SI-006. This work was supported by the LDRD SI proposal PI: Frederik Ryerson. We thank Rob J. Mellors and Eric Matzel providing insightful comments on this project pre-deployment.

We would also like to acknowledge the staffs of AltaRock Energy Inc. Particular thanks goes to Dr. Trenton Cladouhos, our main contact who guided us to the sites and shared his knowledge of the area and Will Osborn for his thoughtful commentary on our deployment. Thank you also to Mr. Cody of Davenport Newberry who helped us dig some of the holes for the seismic sensors.

\section{Site Photos}
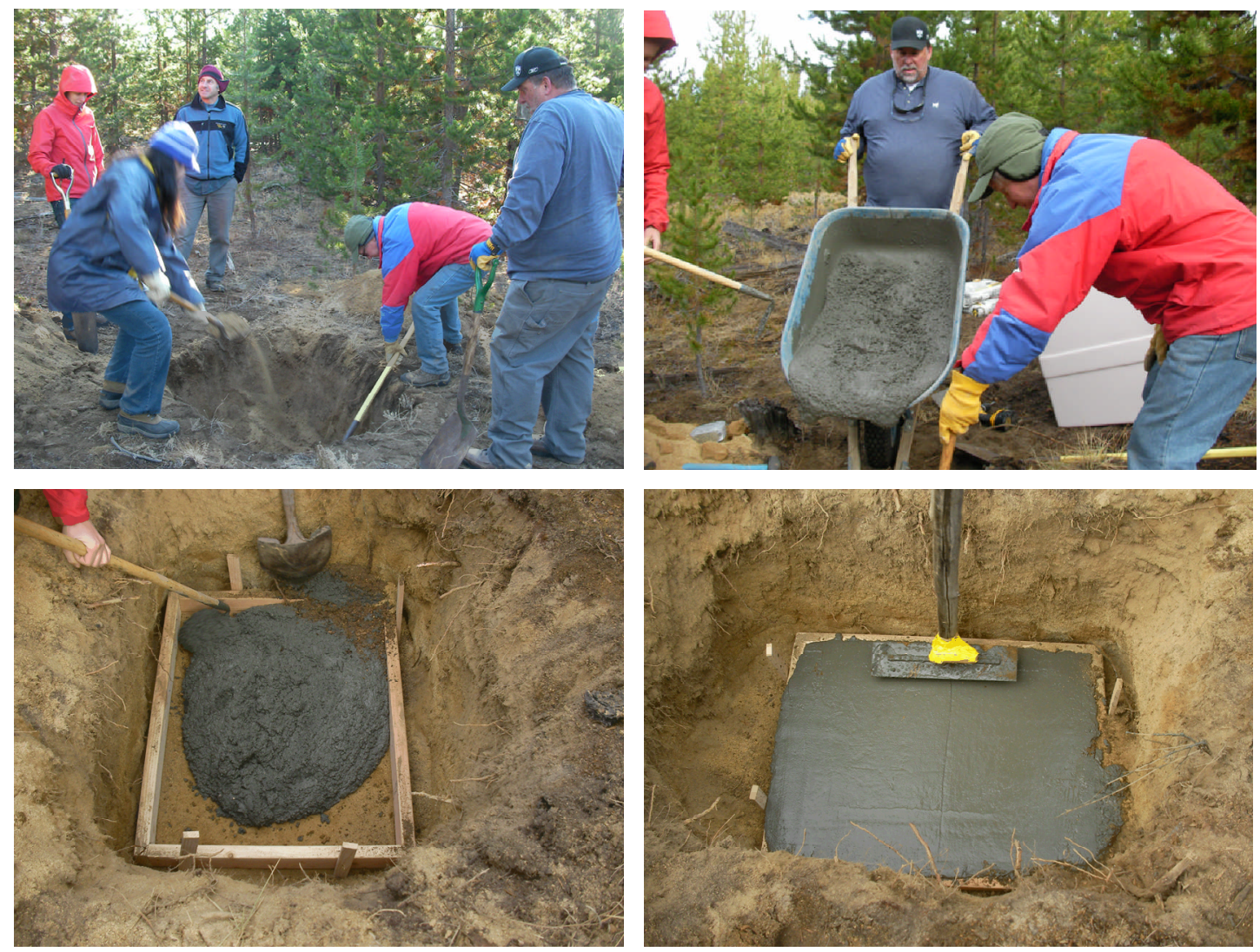

Deployment site preparation: Dig a cavity, make concrete, pour the concrete in the wooden frame and level it using our super tool (created in the field by Phil Harben). 

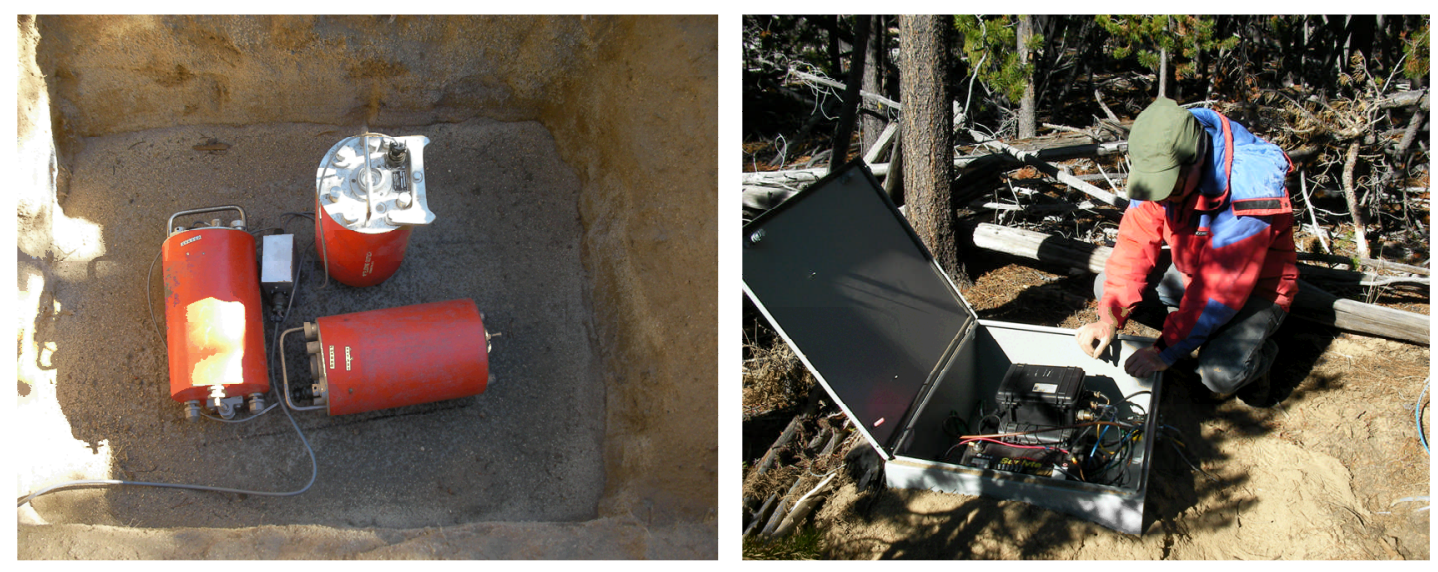

Site installation: Left: seismometers and resistor box on concrete pad. Right: digitizer, batteries, and all cables are well protected in the Hoffman box.
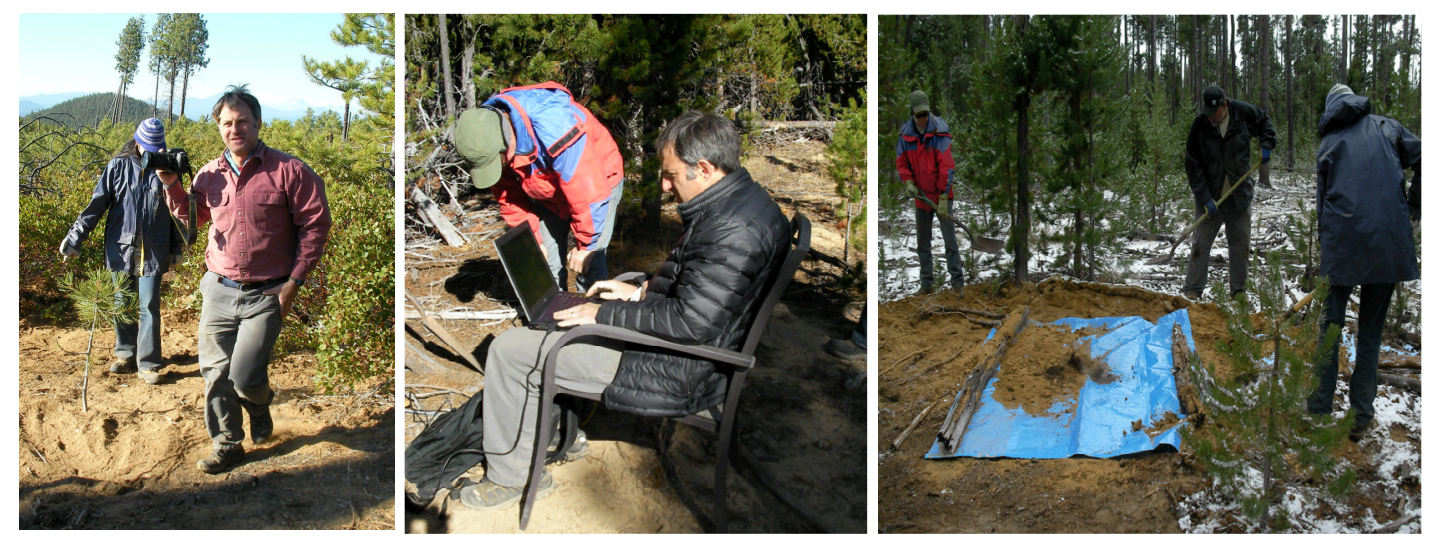

Data quality control: Left to right: Trenton creating an artificial "earthquake", a computer is connected to the digitizer to see whether the seismometer properly recorded the signals, after confirmation of proper recording, we bury the site and cover the plastic tarp with loose soil. 

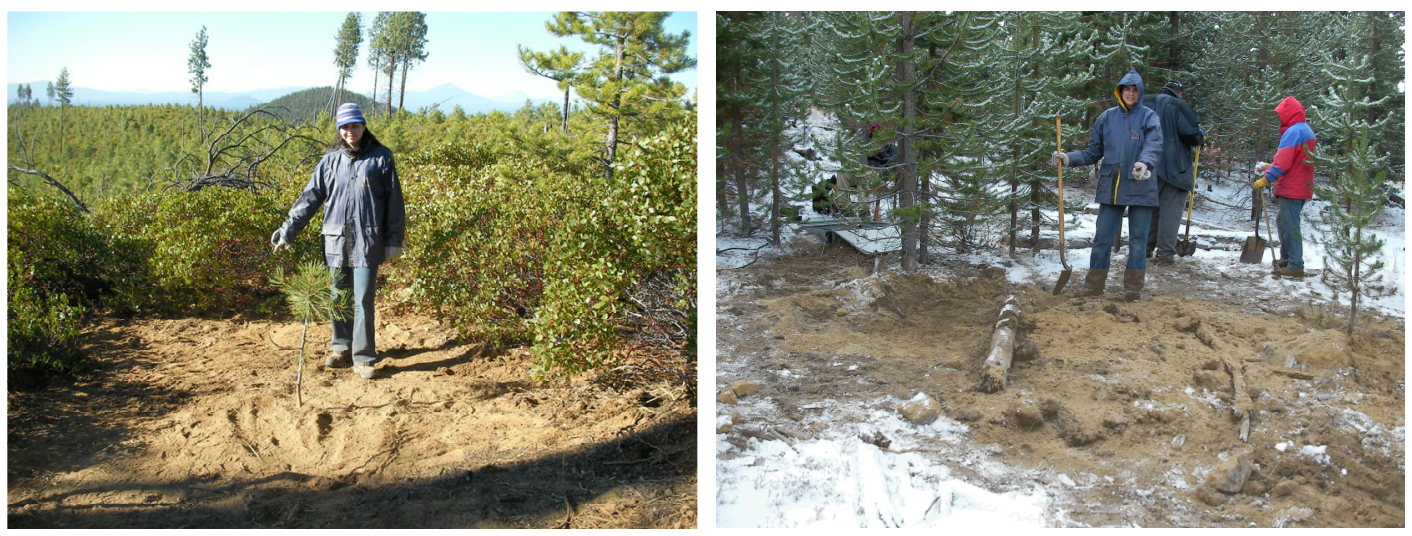

Photos of Sites NBM13 (left) and NBM08 (right) post-deployment. No native plants or trees were removed for the deployment since we deliberately choose locations free of surface vegetation. 